\title{
Image of Russia as the Basis of Metatext for Musical Pieces by Georgy Sviridov
}

\author{
Marija M. Chikhacheva* \\ Krasnoyarsk State Academy of Music and Theatre \\ 22 Lenin Str., Krasnoyarsk, 660049, Russia
}

Received 15.01.2017, received in revised form 24.07.2017, accepted 04.08.2017

This research focuses on the works by an outstanding Russian composer of the $20^{\text {th }}$ century, Georgy Vasilyevich Sviridov. The totality of musical pieces written by the author are studied as a metatext. The key feature of this metatext is the uniqueness of the composer way to interpret the image of Russia, which he regards as something wider than the image of the Motherland. The present article offers different angles of studies based on interdisciplinary approach. The latter discovers some new, unexplored conceptual aspects of the musical heritage of G.V. Sviridov. In particular, the works are regarded in the context of the so-called intuitive mythologism. From this point of view, the works by G.V. Sviridov are researched as an author's myth phenomenon with a typical mythical view outlook with distinctive archetypes and the originality of symbolic linguistic patterns.

Keywords: composer G.V. Sviridov, metatext, image of Russia, author's myth, archetypes, symbolism.

DOI: 10.17516/1997-1370-0122.

Research area: culturology, art criticism.

The motive of historical fate of Russia, and the "Motherland theme" as a wider one play the central role in the musical heritage of several generations of Russian composers. Their works reflect different worldviews and style preferences. Chronologically, it belongs to contrast periods in the history of Russian music, from the times of M.I. Glinka, M.P. Mussorgsky, P.I. Tchaikovsky and to the century of S.S. Prokofiev and G.V. Sviridov. However, despite multiple differences, these composers are united with the key vector in their creative work.

Georgy Vasilyevich Sviridov is one of the most outstanding figures of the $20^{\text {th }}$ century's Russian music. To our mind, his contribution into modern culture has not been fully estimated: the researches dedicated to his music (despite their great number and depth) are still insufficient in comparison with the scale of his personality and the significance of his musical pieces in the $20^{\text {th }}$ century's culture.

However, it would be better to say that the conceptual content of music of classical level, which is the music of G.V. Sviridov's heritage, always exceeds the semantical volume of the whole totality of the published researches, provoking their authors to set new problems and search for new approaches to the musical material.

It would be fair to say that in the totality of articles dedicated to Sviridov, articles by

(C) Siberian Federal University. All rights reserved

* Corresponding author E-mail address: mgokhfeld@yandex.ru 
famous researchers prevail. Those are researches by: A. Sokhor, A. Belonenko, A. Kruchinina, T. Maslovskaia, Iu. Paisov, L. Poliakova, E. Ruchyevskaia, S. Savenko, V. Tsendrovsky, M. Elik. Their works were published in collections with close and sometimes same names: "Georgy Sviridov" (1971), "Georgy Sviridov" (1979), "Book of Sviridov" (1983), "Musical World of Georgy Sviridov" (1990), “G.B. Sviridov in Modern Musical Culture" (2010), as well as in the proceedings of conferences such as "Sviridov Readings" carried out annually by Kursk College named after G.V. Sviridov and once (in 2005) at Petrozavodsk Conservatory.

Peculiarities of performing interpretation of choral pieces by the composer are reflected in two books by V. Zhivov: "Pathetic Oratorio' by Georgy Sviridov" (Zhivov, 1973) and "Vocal and choral music by Georgy Sviridov. Choir conductor's notes" (Zhivov, 2005). Concepts of some candidates' theses, such as "Choir in cantatas and oratorios by G.V. Sviridov: choir thinking principles" by I. Gulesko (Gulesko, 1980) and "Problems of style and interpretation of a cappella chorals by G.V. Sviridov based on cycle 'Five Choruses on Verses of Russian Poets" by E. Legostaev (Legostaev, 1990) are also of great interest.

Issues of creative methods of Sviridov are considered in "...And music and word..." by I. Efimova and T. Vorob'eva (Efimova, Vorob'eva, 2002), as well as in the candidate's thesis "Musical dramaturgy of cantatas, oratorios and chorals by G. Sviridov" by V. Matorina (Matorina, 2010).

An extremely important role in preservation, studies and popularization of the composer's heritage was played by the President of Sviridov's National Foundation A. Belonenko, who worked on publishing of the Full Collection of Sviridov and initiated the publishing of Sviridov's diary records titled "Music as fate" (2002), which is a great help in correct and comprehensive understanding of the musician. The "live word" of the author is also presented in the book "Georgy Sviridov through the memories of his contemporaries" (2006).

Interpretation of G. Sviridov's works through the prism of national traditions was presented in the theses by T. Maslovskaia "On the national entity of works by G. Sviridov (based on cantatas and oratorios)" (Maslovskaia, 1984) and E. Fedulova "Actualization of liturgic traditions in spiritual music by Georgy Sviridov" (Fedulova, 2010). In other words, Sviridov's music is being interpreted through the prism of its connections to the foundations of national culture.

The dominating majority of Sviridov's works are a picture of this or that aspect of our motherland. Let us give some examples of different pieces written in different times and different genres. Those are: "Poem in memory of Sergei Yesenin" (1955-1956), cycle of songs "My father is a peasant" to the poetry by S. Yesenin (1956), "Pathetic oratorio" to lyrics by V. Mayakovski (1959), "St. Petersburg songs" to lyrics by A. Blok (1961-1963), cantata "Songs of Kursk" to folk lyrics (1964), cantata "Wooden Russia” to lyrics by S. Yesenin (1964), cantata "It's snowing" to lyrics by B. Pasternak (1965), "Small Triptych" for full orchestra (1964-1965), "Spring Cantata" to lyrics by N. Nekrasov (1972), poem "Cast off Russia" to lyrics by S. Yesenin (1977), "Hymns to the Motherland" to lyrics by F. Sologub (1978), choral concerto "Pushkin's Garland" (1978), choral poem "Ladoga" to lyrics by A. Prokofiev (1980), "Timeless songs" to lyrics by A. Blok (1980), cantata "The friendly guest” to lyrics by S. Yesenin (1962-1990-s), poem "Petersburg" to lyrics by A. Blok (1995).

The image of Russia created by Sviridov is volatile and antinomic. It is the image of the supertemporal Russia the Heaven, Russia the Eternal, and at the same time Russia the Mundane, in its actual historical reality. At the 
same time, it is a whole artistic world, unique and inimitable, represented in a number of pieces by Sviridov integrated with a "meta-story". This is the reason to come up with the question of the metatext in musical pieces by G.V. Sviridov.

The common motive of this metatext is typologically formed, first of all, by the world of peasant Russia (in cantatas "Wooden Russia" and "Songs of Kursk"), the origin of people's riot (in "Wooden Russia" and "Spring Cantata"); Revolution and the Civil War (understood as a borderline, change of worlds and epochs in "Poem in memory of Sergei Yesenin", in "Pathetic Oratorio", in the cantata "The friendly guest"), and, finally, by the idea and the dream of creating a new world, heaven on Earth (in "Pathetic Oratorio" and in "The friendly guest"); and, to conclude, by the Russian way to spiritual transformation (in poems "Cast off Russia" and "Petersburg"). It is important to emphasize, that these opuses impress not only the historical events, but the spiritual reaction and interpretation of what is happening through the worldview prism of the Poet.

Historicism of G.V. Sviridov's thinking manifests itself in the specific intonational patterns of his music, encompassing a variety of historical layers of Russian musical culture: the archaic folklore, church choral art of the Medieval period, urban (provincial) romance of the $19^{\text {th }}$ century, Soviet mass songs.

Importantly, this mix does not make an impression of eclectics, but makes up a natural alloy that is adequately used to depict the composer's beloved concept, the image of Russia. The inexhaustibility of the latter, compared to the author's asceticism in the selection of expressive techniques seems paradoxical only at first sight. In fact, it reveals the key features of the composer's thinking, his system of highly mastered artistic symbolism. For this reason, the distinctive feature of Sviridov's music formulated both by researchers and simple listeners is described as "genius simplicity".

Sviridov is rightfully considered to be a successor of the many centuries' traditions of Russian musical culture. Expressing his own vision of Russian fate along with the intuitive insights of Russian thinkers in his music, the composer attempted to catch the core of the volatile historical reality, which is the being of national culture, and, consequently, timeless axiological milestones of the culture creating nation.

This desire embodies one of the tendencies typical for the $20^{\text {th }}$ century's art: the search for the conceptual foundations of existence, threatening the human culture and civilization as a whole, despite the changes happening in the world.

One of the backbone lines in the search of the conceptual foundation of existence in the $20^{\text {th }}$ century's art is the conscious or intuitive myth creation (or the so-called neo-mythologism), which, according to the fair statement of V.M. Naidysh, "presents not only the residual splashes of the prehistorical mythopoetic splendour, but also manifestation of some underlying and understudied features of human spirituality" (Naidysh, 2010: 9).

We do not exaggerate if we say that the $20^{\text {th }}$ century is described with the rise of both creative and scientific interest for the myth phenomenon. Literary critics find some traits of mythologism in the works by A. Blok, J. Joyce, S. Yesenin, F. Kafka, G. Marquez, T. Mann, V. Mayakovski, A. Platonov and many other authors; art critics find them in the works by V. Vasnetsov, M. Vrubel, S. Dali, P. Picasso, M. Chagall; music theorists claim it to exist in the music by $\mathrm{Ch}$. Ives，B. Bartok，D. Milhaud，S. Rachmaninov, S. Slonimsky, I. Stravinsky, K. Stockhausen, R. Strauss.

A great number of musicological researches dedicated to myth in music is based, 
predominantly, on the works by R. Wagner, a $19^{\text {th }}$ century composer. Some traits of mythologism are also found in works by M. Glinka, N. RimskyKorsakov, P. Tchaikovsky, A. Borodin, S. Taneev.

It is believed that neo-mythologism in the $20^{\text {th }}$ century's culture is a significant and expected phenomenon which is unanimously defined by such different authors as theologist philosopher S.N. Bulgakov and his junior contemporary, Hungarian philosopher, ethnographer and philologist K. Kerényi.

"Strictly speaking, there is no difference between an artist and a myth-creator in the "transcendent" nature of their competence", wrote S.N. Bulgakov in 1917 (Bulgakov, 1994: 59).

"...An artist $<\ldots>$ is a real creator, founder and "fundamentalist" only when they derive strength from the source where the mythologies come and originate from", is the thought expressed by K. Kerényi as early as in the year 1941 (Kerényi, Jung, 1996: 36).

In the light of the foregoing, it is necessary to remark that the author founds the present study not on the common metaphorical understanding of a myth as a fantasy or fiction remote from reality (including artistic fiction), but on the approach to myth as a scientific category. Let us underline that the researches of myth, as well as encyclopaedic articles, often use the terms "myth" and "mythology" as synonyms. However, "myth" in the narrow meaning is defined as an archaic narration, while "mythology" stands for the science that studies ancient myths.

Approach to myth as a scientific category was developed in various branches of research, such as philosophy, anthropology, linguistics, literary criticism, throughout the entire $19^{\text {th }}$ century in the works by A. Veselovsky, A. Potebnya, F. Schelling and many others, and in the $20^{\text {th }}$ century in the works by R. Barthes, K. Kerényi, E. Cassirer, L. Levy-Bruhl, C. Levy-
Strauss, A. Losev, E. Meletinsky, J. Frazer, M. Eliade, C. Jung.

Perhaps, in the present time we can claim that since the days of S.N. Bulgakov and $\mathrm{K}$. Kerényi the thesis that artistic endeavour is myth creation has moved away from the literary metaphor function and is not understood as a characteristic of a stable (if not permanent) factor for creative processes in music, poetry, painting and dramaturgy.

The formula derived by music theorist $\mathrm{N}$. Beketova and presented in her conceptual article "Absolute myth of Romanticism" looks topical and expected, applicable not only to various styles, but all types of artwork, including artistic cultures of any historical period: "Any creativity is a myth" (Beketova, 1998: 21).

The words of Georgy Vasilyevich Sviridov, who described his own work as a "myth of Russia", sounds absolutely differently from the point of view expressed above (Sviridov, 2002: 404).

This phrase unambiguously states the dominant of the artistic world created by the composer and defines the specificity of his musical language. The mythologism of Sviridov's music was noticed by such outstanding researchers as pianist M.A. Arkadyev, music theorist A.S. Belonenko, composer V.I. Rubin.

The mythological approach to Sviridov music studies brings fruit, because it finds Sviridov to be one of the passionate keepers of the national culture, the "creator of the myth of Russia".

In our opinion, the suggested approach gives an opportunity to find the origins of the unique originality of the artistic world created by the composer, as well as describe the previously unknown edges of his artwork.

As a scientific reflection object, the myth is an indissoluble unity of three aspects:

- Myth as a certain form of consciousness representing the integrated picture of the world, 
or, in other words, a specific way of interaction between person and the world (L. Levy-Bruhl, E. Meletinsky, O. Freidenberg, C.-G. Jung);

- Myth as a special picture of the world composed from the aggregate of archaic legends, a "mythical" picture (A. Potebnya, A. Losev, E. Meletinsky, V. Toporov, M. Eliade);

- Myth as a special "meta-language" (R. Barthes, S. Bulgakov, C. Levy-Strauss, A. Losev, E. Meletinsky, V. Toporov).

Scientific literature presents a great number of various definitions of "myth", but despite all the differences between them they are similar in the core. In our opinion, the most succinct definition, expressing the integrity of the myth and its three-aspects in the "minimized outline", was formulated by A.F. Losev: "myth is miraculous, personalized [faith and thinking as epistemological and axiological aspects] history [picture of the world, ontological aspect] presented in words [language as semiotic and communicative aspects]" (Losev, 1994: 195) (in brackets the comments of the author are presented).

In correlation with this definition, Sviridov's myth may be characterized as a personalized "miraculous history" of Russia, narrated in the language of music and absorbing national cultural archetypes. Naturally, in respect with the artwork of the $20^{\text {th }}$ century composer we speak of a modern author's myth (examples of modern artistic myth creation are shown, for instance, in works by R. Barthes, E. Meletinsky, M. Epshtein).

Modern myth inherits the structure and properties of the archaic myth, typical only to the ancient forms of thinking.

However, the determining and the distinctive trait of modern myth is interaction between the mythical (archaic) and non-mythical consciousness, which manifests itself at all levels of the modern myth structure. The myth actualized in art pieces is mediated in this or that way (modern author's myth phenomenon).

Consequently, now, just like before, at least since the Renaissance, artistic thinking is absolutely not equal to mythical (archaic) one. In such cases (for example, in opera seria) the subject matter is some single representations of the latter in the first (intentional, immediate, intuitive, adaptive).

The structure and contents of the mythical picture of the world consists of a series of archetypes, ultimately sustainable, fundamental, ancient, universal mythical motives. For example, the archetype of creation is presented as a mythologeme of world creation, creation of human, Heaven or Garden of Eden (the initial world).

Along the collective unconscious archetypes outlined by C.-G. Jung in the sphere of psychoanalysis (for instance, the archetypes of the eternal child, the virgin, the mother, the resurrection, the anima, the trickster), scientific researches consider some others generally referred to as "eternal concepts". Such generalization looks fair, at least, within the framework of the structural-typological approach to myth study suggested by C. Levy-Strauss.

A great number of theses on musical theory written in the past years are dedicated to the problem of actualization of mythical archetypes and mythologemes (Denisov, 2008; Petrushevich, 2008; Ponomareva, 2012).

However, the author of the present article concentrates on a certain set of archetypes that form the "backbone" or the invariant of the mythical picture of the world. Such invariant (or "world model") suggested by V.N. Toporov based on the archaic myth analysis, consists of the initial "patterns" of mythical texts, such as: cosmological arrangement, arrangement of family and marriage relations, mythic and historical tradition schemes. 
The structural fundament of the world model is formed by the spatial and temporal "axis"; the organizing principle is the principle of opposition (A. Losev, E. Meletinsky). That means that the world model structure is based on contrasts (normally, binary oppositions) of up-down, skyearth, past-future, water-fire, insider-outsider.

Comparing various researches of general myth theory with the "initial patterns" of Toporov's world model, the author of the article arrives at the conclusion on the existence of the so-called basic archetypes essential for the integrity of the mythical picture of the world. Those are: the archetypes of creation, heroes, demiurges, ancestors, the archetype of initiation, the death of the world.

The variative archetypes (from the point of view of their structural function in the mythical picture of the world) may include: the archetypes of the divine mother, the twin (shadow), the soul, the home, and various zoomorphic archetypes. The terms of "basic archetype" and "variative archetype" are suggested by the author of the present article.

The archetype of creation plays a special role in cosmological legend-myths telling the story of creation of the world, time and celestial bodies; it sets the spatial and chronological coordinates for the world picture. In the stories of the primary harmony and beauty of creation, the archetype of creation is tied to the image of Heaven (Heaven or Garden of Eden as one of the constants in such mythic legends).

The archetype of heroes, demiurges and ancestors is an attribute of stories "filling" the world picture with certain content, i.e. the "stories" of deeds of its "actors".

The archetype of initiation is actualized in the narrations regulating the life of myth heroes (and, through it, the lives of the myth bearers) and explaining the reasons for their actions. The archetype of the death of the world (or the archetype of the border) reflects eschatological ideas.

Besides archetypes, the world picture of the modern (author's) myth also includes some kenotypes (term by M.N. Epshtein), i.e. sustainable universal or national motifs developed within the visible and certainly known historical situations.

This is the picture of the world presented in the works by G.V. Sviridov: it is integrity of basic archetypes and kenotypes, or, in essence, a metatext, the structure of which corresponds to the mythical world picture structure.

The archetype of creation is found in the pieces where the composer depicts the supertemporal, superhistorical image of Russia, the image of a perfect world, the Heavenly Russia. This is the world of miraculous past, the heir of which is the world of peasant Russia; but, at the same time, it is the world of the future, either the man-made Heaven on Earth or spiritual transformation of Russia in the Celestial Kingdom.

The archetype of the hero, and partially of demiurge is actualized in Sviridov's myth through the mythologeme of the Poet, traditional for the modern age art. The Poet absorbs the image of the Prophet Poet existing in Russian poetry, as well as typical features of epos heroes and chroniclers, the witnesses of Russian history (Sadko, Bayan, Nestor, Pimen).

It is through the prism of the Poet's internal microcosm the world picture as macrocosm, the image as it is, to this or that extent aids the integration of artistic factors into a single whole.

Among other heroes of the mythical "narration" there are: People (the collective image that can be compared to the personified image of Yesenin's Muzhik); Wrangel and Lenin, not as political figures, but historically unrelated mythical heroes.

The archetype of initiation is presented with the mythologeme of mother Earth, which always 
presents the sacred core of Sviridov's myth. The love for the Motherland unites the heroes and determines their deeds, and admission to the Mother Earth is compared to ancient initiation rituals.

The archetype of the death of the world in Sviridov's world picture is frequently transformed into a kenotype. In this certain case, the eschatological ideas are concentrated around a certain historical event, which is the Revolution of 1917, interpreted as a borderline between the old, dying world of the Peasant Rus and the brand-new conceiving world of the Soviet Russia.

The archetype (kenotype) of the death of the world influences the archetype of Heaven in such aspects as the man-made Heaven created by the power of revolutionary Russia, and Heavenly Russia, the Uncreated, Divine concept of Russia.

The structure and contents of the above world picture in the musical myth of Russia composed by G.V. Sviridov are shaped with specific expressive techniques, giving some features of the myth language to the language of music.

The mythical picture archetypes are represented as mythologemes of various traditions. In their turn, at the linguistic level the mythologemes are expressed through the verbal signs referred to as "mythemes" (term by C. Levy-Strauss).

From the point of view of its linguistic peculiarities, the concept of myth is described in detail by A.F. Losev, who gives priority to the symbolic nature of the myth language: "any myth is a symbol" (Losev, 1976: 174).

The original symbolism of the myth language was mentioned by S.N. Bulgakov, Ia.E. Golosovker, Viach. I. Ivanov, K. Kerényi, E.M. Meletinsky.

The problem of actualizing myth at the musical and linguistic level is considered in a number of musical theory researches. The works by V. Val'kova, T. Il'ina, O. Perich connect the manifestation of some mythical thinking features at the linguistic level to the diffused thematic invention phenomenon. L. Akopian correlates the role of Levy-Strauss' mythemes to the similar function of leit-motifs in Wagner's musical dramas. The connection between mythologism and the expressive means' symbolism in music by Rachmaninov was found by E. Vartanova and N. Beketova.

Generally speaking, the connection between mythologism and symbolism is also observed in G. Sviridov's music. Even this fact can serve as a basis to regard the picture of Russian world depicted in the composer's opuses as a national variant of the mythical world picture, or, to be more precise, its individual author's interpretation. Symbolism as a typical feature of Sviridov's musical language was pointed out by such researchers as A. Belonenko, A. Kruchinina, A. Predoliak, T. Cherednichenko and many others. It goes without saying that the term "symbolism" is understood in the wide meaning applicable to different epochs. The author of the present article follows the same terminological tradition.

Such essential features as intuitive resort to the archaic, mythical images, as well as the presence of certain author's linguistic means matching the nature of those images, witness the belonging of Sviridov's interpretation of the "myth of Russia" to the so-called "organic mythologism" (term by V.N. Toporov).

Finding specific linguistic techniques is the primary task. According to C. Levy-Strauss, resorting to the myth, one "cannot start learning grammar avoiding vocabulary" (Levi-Strauss, 1983: 428).

Since the artistic mythological piece phenomenon is faced by a researcher as a number of differentiated conceptual units, or mythemes, in their combination with some semantic integral, 
i.e. the myth itself, then the process of research may be begun from any end of the chain.

We can either follow the C. Levy-Strauss' tradition and begin with the differentials, or mythemes, the knowledge of which provides ultimate organicity of perception in the studied national factors. But it brings an inevitable shortcoming: outside the mythological context, mythemes are unlikely to unite into a single mythological narration.

Or we can turn to the tradition of C. Jung and K. Kerényi, and begin with the historical and artistic fundamental integral, the myth as such, which is the starting point of historical development of the subordinate mythemes, that does not lose its basic function in the event of loss of one or several units of mythological symbolism.

Together with that, integration of mythemes into sustainable conceptual chains or semantically tied groups significantly strengthens their role in the gradual historical formation of the myth, or in the comparatively rapid creation of the individual artistic mythology by the author, the poet, composer, or dramaturg.

The question of musical mythemes of G.V. Sviridov's artwork (or the symbolism of the composer's musical language) is described in more detail in the dissertation by M.M. Luchkina "Myth of Russia in the artwork by G.V. Sviridov" (Luchkina, 2012).
Moreover, some analytical observations let us speak of certain traits of mythical thinking manifested in music by Georgy Sviridov. Such typical features as separation of the mundane/ ideal and orientation to the ideal are actualized in the contrast of the terrestrial and the celestial conceptual-intonational spheres. Each component of the author's world picture (regardless of its positive or negative "charge") is essentially correlated to the ideal, the image of Rus the Sacred. It brings the world picture to a sacred dimension, the source of which is the faith as an inherent element of myth consciousness without which the myth cannot exist.

It brings us to the conclusion that the artistic world created by the composer organically shows some features of a myth. In other words, Sviridov's myth vividly shows its axiological, ontological, epistemological, semiotic and communicative aspects of the archaic myth. It sets a certain scale of axiological milestones, it uses special linguistic means to express the underlying foundation of artistic reality which sets some questions to the perceiving consciousness and gives the author's answer to "What is Russia? How and where does it go?"

It is believed that the studies of musical heritage of Georgy Sviridov in the mythological key can be expanded and applied to works by other authors with a tendency to myth creation.

\section{References}

Beketova, N. (1998). "Absoliutnyy mif” romantizma [The absolute myth of Romanticism]. Muzykal'nyy mir romantizma: ot proshlogo $k$ budushchemu [Musical world of Romanticism: from past to future]. Rostov-on-Don, 21-24.

Borisenko, I., Grigoryeva, G. (2015). National images of countries in intercultural interaction of world civilizations in the modern period, In Journal of Siberian Federal University. Humanities \& Social Sciences 9, (8), 1955-1964.

Bulgakov, S. (1994). Svet Nevecherniy. Sozertsaniia i umozreniia [Light Unfading. Contemplation and Meditation]. Moscow, $415 \mathrm{p}$.

Georgii Sviridov v vospominaniiakh sovremennikov [Georgii Sviridov in the memoirs of contemporaries]. Moscow, 2006. 763 p. 
Denisov, A. (2008). Antichnye mifologicheskie opernye siuzhety v kontekste kul'tury pervoy poloviny XX veka [Ancient mythological opera storylines in the cultural context of the first half of the twentieth century]: Abstract of dissertation for the degree of Doctor of Art criticism. St. Petersburg, $36 \mathrm{p}$.

Efimova, I., Vorob'eva, T. (2002). ...I muzyka i slovo (O tvorcheskom metode G.V. Sviridova) [“... And music and words" (on creative method of G.V. Sviridov)]. Krasnoyarsk, 164 p.

Epshtein, M. (1988). Paradoksy novizny: O literaturnom razvitii XIX-XX vekov [Paradoxes of novelty: literary development of the 19-20 th centuries]. Moscow, 1988. $414 \mathrm{p}$.

Fedulova, E. (2010). Pretvorenie liturgicheskikh traditsiy v dukhovnoy muzyke Georgiia Sviridova [Actualization of liturgical traditions in church music by Georgy Sviridov]: Abstract of dissertation for the degree of Candidate of Art criticism. Magnitogorsk, $25 \mathrm{p}$.

Kerényi, K., Jung, C.-G. (1996). Vvedenie v sushchnost' mifologii [An introduction to the nature of mythology]. In Jung, C.-G. Dusha i mif: shest" arkhetipov [Soul and myth: six archetypes]. Kiev, 11-208.

Khrenov, N. (2014). Russkaia revoliutsiia v kontekste istorii stolknoveniia tsivilizatsiy [Russian revolution in the context of the history of the clash of civilizations], In Voprosy kul 'torologii [Issues of culturology], (12), 35-45.

Levi-Strauss, C. (1983). Struktura i forma [Structure and form], In Semiotika [Semiotics]. Moscow, 400-428.

Legostaev, E. (1990). Problemy stilia i interpretatsiia khorov a cappella G.V. Sviridova [The problem of style and interpretation of a cappella chorals by G.V. Sviridov]: Abstract of dissertation for the degree of Candidate of Art criticism. Moscow, $25 \mathrm{p}$.

Losev, A. (1994). Dialektika mifa [Dialectics of Myth], In Losev, A. Mif. Chislo. Sushchnost [Myth. Number. Quintessence]. Moscow, 5-216.

Losev, A. (1976). Problema simvola i realisticheskoe iskusstvo [Problem of Symbol and Realistic Art]. Moscow, $367 \mathrm{p}$.

Luchkina, M. (2012). Mif o Rossii v tvorchestve G.V. Sviridova [The Myth of Russia in the G.V. Sviridov's works]: Dissertation for the degree of Candidate of Art criticism. Krasnoyarsk, $317 \mathrm{p}$.

Maslovskaia, T. (1984). O national'noy sushchnosti proizvedeniy G. Sviridova [About national identity of G. Sviridov's works]: Dissertation for the degree of Candidate of Art criticism. Moscow, $134 \mathrm{p}$.

Matorina, V. (2010). Muzykal 'naia dramaturgiia kantatno-oratorial'nykh i khorovykh soshineniy G. Sviridova [Musical Dramaturgy of cantata-oratorio and choral works by G. Sviridov]: Abstract of dissertation for the degree of Candidate of Art criticism. Leningrad, $23 \mathrm{p}$.

Naidysh, V. (2010). Mifologiia [Mythology]. Moscow, 432 p.

Petrushevich, Iu. (2008) Arkhetipicheskie motivy v opernom tvorchestve N.A. RimskogoKorsakova [Archetypal motifs in operas by N.A. Rimsky-Korsakov]: Abstract of dissertation for the degree of Candidate of Art criticism. Moscow, $27 \mathrm{p}$.

Ponomareva,E.(2012).Mifopoetikai intertekstual 'nost'vpozdnemtvorchestveP.I. Tchhaikovskogo [Mythopoetics and intertextuality in later works by P.I. Tchaikovsky]: Abstract of dissertation for the degree of Candidate of Art criticism. Saratov, $26 \mathrm{p}$.

Sokhor, A. (1972). Georgiy Sviridov [Georgy Sviridov]. Moscow, 319 p. 
Sviridov, G. (2002). Muzyka kak sud'ba [Music as fate]. Moscow, 800 p.

Toporov, V. (1995). Mif. Ritual. Simvol. Obraz [Myth. Ritual. Symbol. Image]. Moscow, 623 p.

Zhivov, V. (1973). "Pateticheskaia oratoriia” Georgiia Sviridova [Pathetic Oratorio by Georgy Sviridov]. Moscow, $69 \mathrm{p}$.

Zhivov, V. (2005). Vokal'no-khorovaia muzyka Georgiia Sviridova. Zametki khorovogo dirizhera [Vocal and choral music by Georgy Sviridov. Notes of choir conductor]. Moscow, 272 p.

\section{Образ России как основа метатекста \\ музыкального творчества \\ Георгия Свиридова}

М.М. Чихачёва

Красноярский государственный институт искусств

Россия, 660049, Красноярск, ул. Ленина, 22

В иентре внимания статьи - творчество выдающегося отечественного композитора XX столетия Георгия Васильевича Свиридова. Совокупность музыкальных произведений композитора рассматривается автором статьи как метатекст. Ключевые характеристики этого музыкального метатекста видятся в своеобразии трактовки композитором образа Россиишире образа Родины. В настоящей статье предлагаются новые ракурсы исследования творчества композитора, базируюшиеся на междисииплинарном подходе. Последний позволяет вскрыть новые, не рассматриваемые ранее, содержательные аспекты музыкального наследия Г.В. Свиридова. В частности, творчество Г.В. Свиридова рассматривается в контексте так называемого интуитивного мифологизма. С позиций подобного подхода метатекст творчества Г.В. Свиридова исследуется как феномен авторского мифа с присущей ему характерной структурой мифической картины мира с выделением архетипов и своеобразием символического языкового уровня.

Ключевые слова: композитор Г.В. Свиридов, метатекст, образ России, авторский миф, архетипь, символизм.

Научная специиальность: 24.00.00 - культурология, 17.00.00-искусствоведение. 